\title{
Antioxidant activity of various plant sprouts extracts depending on the processing method of plant material - an in vitro study
}

\author{
ANNA MUZYKIEWICZ-SZYMAŃSKA*1, JOANNA ZIELONKA-BRZEZICKA ${ }^{1}$, JOANNA SIEMAK ${ }^{2}$, \\ ADAM KLIMOWICZ ${ }^{1}$
}

\author{
${ }^{1}$ Chair and Department of Cosmetic and Pharmaceutical Chemistry \\ Pomeranian Medical University in Szczecin \\ Powstańców Wielkopolskich 72 \\ 70-111 Szczecin, Poland \\ ${ }^{2}$ Student Research Club at the Department of Cosmetic and Pharmaceutical Chemistry \\ Pomeranian Medical University in Szczecin \\ Powstańców Wielkopolskich 72 \\ 70-111 Szczecin, Poland \\ *corresponding author: phone: +48 9146616 30, e-mail: anna.muzykiewicz@pum.edu.pl
}

\section{Summary}

Introduction: Due to the content of nutrients and taste attributes, the plant sprouts could become a valuable component of a healthy diet.

Objective: The aim of the study was to evaluate the antioxidant potential of various sprouts extracts depending on the processing method of the plant material.

Methods: The extracts in $96 \%(v / v)$ ethanol were prepared from fresh, frozen, dry and homogenized sprouts of alfalfa, broccoli, radish, lentil, mung bean, beetroot, sunflower, and kale, using ultrasound-assisted extraction. The antioxidant potential and total polyphenols content were evaluated by the in vitro methods.

Results: The highest antioxidant activity was observed for beetroot and kale as well as broccoli sprouts extracts. The lower potential, in general, was observed in the case of alfalfa, lentil, and mung bean sprouts samples. The lowest activity was observed most frequently for the extracts from dry material, whereas the highest for homogenized as well as frozen and fresh.

Conclusion: The plant sprouts, particularly beetroot, kale, and broccoli, could be a valuable source of natural antioxidants. 


\title{
Key words: sprouts, antioxidant activity, ultrasound-assisted extraction, food processing methods
}

\author{
Słowa kluczowe: kiełki, aktywność antyoksydacyjna, ekstrakcja wspomagana ultradźwiękami, \\ metody przetwarzania żywności
}

\section{INTRODUCTION}

Plants are a valuable source of biologically active substances with a positive impact on human health. This group of compounds includes, among others, antioxidants that help to decrease the risk of development of oxidative stress and to prevent its harmful effect on human organism [1]. Substances with antioxidant potential can be found in different parts of plants: fruit, seeds, leaves, roots or sprouts formed from the seeds during the initial growth phase called germination. Due to this fact, they are characterized by a high content of nutrients. Sprouts are a source of vitamins (mainly A, B, C, E, H), enzymes, minerals, phenolic compounds, amino acids, as well as dietary fiber. The profile and content of biologically active compounds depend on the germ species. For example, mung bean sprouts are rich in vitamins $A$ and $B_{6}$, while radish sprouts contain ascorbic acid. The alfalfa sprouts are a source of exogenous amino acids [2-4]. Depending on the type, sprouts of various leguminous plants or cereals have a specific taste. For example, alfalfa sprouts have a tart, slightly nutty taste, whereas radish sprouts are spicy. In recent years, the nutritional and pro-health properties of sprouts aroused the interest of experts. It has been proven that sprouts have a higher nutritional value than the seeds they came from. Therefore, it has been a reason to include them as an important component of a healthy, well-balanced diet $[4,5]$. Taking into account the permanent search for new sources of natural antioxidants, it has been decided to evaluate the antioxidant activity of the extracts from various types of sprouts. Moreover, the impact of commonly used food processing methods on the antioxidant potential, such as freezing, drying or homogenization of the obtained extracts was also analyzed.

\section{MATERIAL AND METHODS}

\section{Chemicals}

DPPH (2,2-diphenyl-1-picrylhydrazyl), TPTZ (2,4,6-tris(2-pyridyl)-s-triazine), ABTS (2,2'-azino-bis(3-ethylbenzothiazoline-6-sulfonic acid) and Trolox (6-hydroxy-2,5,7,8-tetramethylchromane-2-carboxylic acid) were purchased from Sigma-Aldrich (St. Louis, USA); gallic acid, FolinCiocalteu reagent and iron(II) sulfate heptahydrate were obtained from Merck (Darmstadt, Germany); copper(II) chloride dihydrate, methanol, potassium persulfate, $36 \%$ hydrochloric acid, iron(III) chloride hexahydrate, 99,5\% acetic acid, sodium acetate anhydrous and sodium carbonate anhydrous were obtained from Chempur (Piekary Śląskie, Poland); whereas ethanol and neocuproine were obtained from Linegal Chemicals (Warszawa, Poland) and J\&K Scientific (Beijing, China), respectively. All reagents were of analytical grade.

\section{Plant material and extracts preparation}

The plant material consisted of alfalfa (Medicago sativa L.), broccoli (Brassica oleracea L. var. italica Plenck), radish (Raphanus raphanistrum subsp. Dativus), lentil (Lens culinaris Medik.), mung bean (Vigna radiata), beetroot (Beta vulgaris L.), sunflower (Helianthus annuus L.) and kale (Brassica oleracea L. var. sabellica L.) sprouts. The sprouts were purchased at a local supermarket (in 2019) and were obtained from Polish crops. The whole fresh, frozen $\left(24 \mathrm{~h}\right.$ at $\left.-20^{\circ} \mathrm{C}\right)$ and dry $\left(24 \mathrm{~h}\right.$ at $\left.+40^{\circ} \mathrm{C}\right)$, as well as the homogenized sprouts with the solvent ( $3 \mathrm{~min}, 10000 \mathrm{rpm}$, IKA T18D Ultra Turrax ) were used as plant material and 96\% $(v / v)$ ethanol as extractant. The fresh, frozen and dry sprouts were extracted for $60 \mathrm{~min}$ using ultrasound-assisted extraction $(40 \mathrm{kHz})$. The obtained 5\% extracts were stored in the refrigerator at $+4^{\circ} \mathrm{C}$ (up to 7 days) until the analysis.

\section{Antioxidant activity and total polyphenols con- tent determination}

To evaluate the antioxidant activity of extracts, the DPPH, ABTS, FRAP methods were used, as described by Muzykiewicz et al. [6]. The total polyphenols content, determined by Folin-Ciocalteu (F-C) method, was also carried out as previously described by Muzykiewicz et al. [6]. The cupric reducing antioxidant capacity (CUPRAC) was performed 
according to the procedure described by Apak et al. [7]. The absorbance of samples was measured in $1 \mathrm{~cm}$ cuvettes using Hitachi U-5100 spectrophotometer. Data are presented as arithmetical means calculated from 3 independent measurements of extracts \pm standard deviation (mean \pm SD). For DPPH, ABTS and CUPRAC methods, the results were expressed as TEAC (Trolox equivalent antioxidant activity - mg Trolox/g plant material). The results obtained by FRAP technique were presented as $\mathrm{mM}$ $\mathrm{Fe}^{2+} / 100 \mathrm{~g}$ plant material, whereas those obtained by the Folin-Ciocalteu method as GAE (gallic acid equivalent - mg GA/g plant material). In the case of fresh and homogenized sprouts, the results were calculated and expressed as $\mathrm{mg}$ or $\mathrm{mM}$ of reference substance/g fresh material, whereas for frozen and dry sprouts as $\mathrm{mg}$ or $\mathrm{mM}$ of reference.

\section{Statistical analysis}

The one-way analysis of variance ANOVA (significance level $p<0.05$ ) was used to evaluate the results. The mean values were grouped separately, taking into account the type of sprouts (alfalfa, broccoli, radish, lentil, mung bean, beetroot, sunflower, kale), the method of preparation of plant material before extraction process (fresh, frozen, dried and homogenized) as well as the method of evaluating the antioxidant activity (DPPH, ABTS, CUPRAC, FRAP and the total polyphenols content evaluated by $\mathrm{F}-\mathrm{C}$ ). To compare the means, Tukey's multiple range test $(n=3)$ was applied. Pearson's correlation coefficients (r) between the antioxidant potential of all sprouts extracts, evaluated by all of the applied methods were also calculated. The differences between activities (evaluated by all applied methods) of particular sprouts extracts were estimated, using the Wilcoxon signed-rank test (parameter $\mathrm{z}$ ). The statistical analysis was done using Statistica 13.1 (Statsoft, Poland).

Ethical approval: The conducted research is not related to either human or animal use.

\section{RESULTS}

\section{Antioxidant activity of extracts}

Antioxidant activities of extracts, determined by DPPH, ABTS, CUPRAC and FRAP methods are summarized in table 1 . All the extracts evaluated by DPPH, ABTS and FRAP methods showed the antioxidant potential. In the group of extracts estimated by DPPH method, the highest potential was observed for the extract of homogenized beetroot sprouts, whereas the lowest for the extracts of homogenized lentil and frozen mung bean sprouts. The highest potential obtained by ABTS method was also found for the extract of homogenized beetroot sprouts, while the lowest for the samples prepared from frozen alfalfa sprouts. Only a few extracts evaluated by the CUPRAC method have not shown the ability to reduce the cupric ions. The highest ability to reduce cupric ions was found for the extract of homogenized kale sprouts. The lowest activities obtained by the FRAP method were observed for extracts of fresh mung bean and dry alfalfa sprouts, whereas the highest for fresh kale sprouts sample.

\section{Total polyphenols content in extracts}

Table 2 presents total polyphenols content evaluated by the Folin-Ciocalteu technique. All extracts were characterized by the content of polyphenols. The highest content of these compounds was found for the extracts of homogenized as well as fresh kale sprouts, whereas the lowest for frozen mung bean sprouts sample.

\section{Statistical analysis}

The correlation coefficients between the results obtained by the different methods are presented in table 3 , whereas the differences between activities of a particular group of sprout+s, estimated by the Wilcoxon signed-rank test in table 4 . Analysis of the correlation between antioxidant potential of extracts, estimated by all of applied methods showed that these relationships are statistically significant $(p<0.001)$. The highest correlation coefficients were found between the FRAP vs. F-C as well as F-C vs. CUPRAC methods (tab. 3). The differences between the activities of extracts of particular sprouts evaluated by the Wilcoxon signed-rank test were statistically significant in the majority of studied groups (tab. 4).

\section{DISCUSSION}

The sprouts are known as valuable components of a healthy diet due to the content of proteins, enzymes, 
Table 1

The antioxidant activity of sprout extracts evaluated by DPPH, ABTS, CUPRAC and FRAP methods

\begin{tabular}{|c|c|c|c|c|c|}
\hline \multirow{3}{*}{ Sprout } & \multirow{3}{*}{$\begin{array}{l}\text { Type of raw } \\
\text { material }\end{array}$} & \multicolumn{4}{|c|}{ The method of antioxidant activity evaluation } \\
\hline & & $\mathrm{DPPH}$ & ABTS & CUPRAC & FRAP \\
\hline & & & lox/g plant $n$ & & $\begin{array}{c}\mathrm{mM} \mathrm{Fe}^{2+} / \\
100 \mathrm{~g} \text { plant material }\end{array}$ \\
\hline \multirow{4}{*}{ Alfalfa } & fresh & $0.13 \pm 0.03^{\text {a }}$ & $0.27 \pm 0.01 \mathrm{ab}$ & $0.27 \pm 0.03^{c}$ & $0.28 \pm 0.03^{\mathrm{a}}$ \\
\hline & homogenized & $0.16 \pm 0.03^{\mathrm{a}}$ & $0.48 \pm 0.05^{\mathrm{a}}$ & $1.11 \pm 0.10^{\mathrm{a}}$ & $0.28 \pm 0.00^{\mathrm{a}}$ \\
\hline & frozen & $0.11 \pm 0.03^{\text {a }}$ & $0.15 \pm 0.03^{\mathrm{b}}$ & $0.75 \pm 0.04^{\mathrm{b}}$ & $0.27 \pm 0.01 \mathrm{ab}$ \\
\hline & dry & $0.10 \pm 0.02^{\mathrm{a}}$ & $0.48 \pm 0.04^{\mathrm{a}}$ & NA & $0.23 \pm 0.01^{\mathrm{b}}$ \\
\hline \multirow{4}{*}{ Broccoli } & fresh & $1.23 \pm 0.03^{\mathrm{b}}$ & $1.17 \pm 0.04^{\mathrm{c}}$ & $4.34 \pm 0.16^{b}$ & $1.84 \pm 0.04^{\mathrm{a}}$ \\
\hline & homogenized & $1.42 \pm 0.07^{\mathrm{a}}$ & $1.79 \pm 0.08^{\mathrm{b}}$ & $4.64 \pm 0.05^{\mathrm{ab}}$ & $1.85 \pm 0.04^{\mathrm{a}}$ \\
\hline & frozen & $1.01 \pm 0.08^{\mathrm{c}}$ & $2.22 \pm 0.07^{\mathrm{a}}$ & $4.68 \pm 0.15^{\text {a }}$ & $1.83 \pm 0.11^{\mathrm{a}}$ \\
\hline & dry & $0.94 \pm 0.05^{\mathrm{c}}$ & $1.67 \pm 0.07^{\mathrm{b}}$ & $2.75 \pm 0.08^{\mathrm{c}}$ & $1.18 \pm 0.00^{\mathrm{b}}$ \\
\hline \multirow{4}{*}{ Radish } & fresh & $0.64 \pm 0.05^{\mathrm{a}}$ & $1.76 \pm 0.09^{b}$ & $3.22 \pm 0.09^{\mathrm{c}}$ & $1.14 \pm 0.04^{\mathrm{b}}$ \\
\hline & homogenized & $0.74 \pm 0.02^{\mathrm{a}}$ & $1.91 \pm 0.14^{\mathrm{ab}}$ & $4.59 \pm 0.26^{\mathrm{a}}$ & $1.37 \pm 0.02^{\mathrm{a}}$ \\
\hline & frozen & $0.73 \pm 0.05^{\mathrm{a}}$ & $2.03 \pm 0.11^{\mathrm{a}}$ & $4.02 \pm 0.04^{b}$ & $1.36 \pm 0.02^{\mathrm{a}}$ \\
\hline & dry & $0.11 \pm 0.01^{\mathrm{b}}$ & $0.67 \pm 0.02^{c}$ & $0.33 \pm 0.01^{\mathrm{d}}$ & $0.31 \pm 0.02^{c}$ \\
\hline \multirow{4}{*}{ Lentil } & fresh & $0.36 \pm 0.03^{\mathrm{a}}$ & $1.20 \pm 0.04^{b}$ & $0.79 \pm 0.09^{\mathrm{a}}$ & $0.45 \pm 0.03^{\mathrm{a}}$ \\
\hline & homogenized & $0.01 \pm 0.00^{\mathrm{c}}$ & $0.75 \pm 0.04^{\mathrm{d}}$ & $0.61 \pm 0.02^{\text {a }}$ & $0.33 \pm 0.03^{b c}$ \\
\hline & frozen & $0.03 \pm 0.00^{\mathrm{bc}}$ & $2.07 \pm 0.07^{\mathrm{a}}$ & $0.13 \pm 0.01^{\mathrm{b}}$ & $0.37 \pm 0.01 \mathrm{ab}$ \\
\hline & dry & $0.08 \pm 0.02^{\mathrm{b}}$ & $0.90 \pm 0.01^{\mathrm{c}}$ & NA & $0.26 \pm 0.05^{\mathrm{c}}$ \\
\hline \multirow{4}{*}{ Mung bean } & fresh & $0.11 \pm 0.03^{\text {a }}$ & $0.73 \pm 0.05^{b}$ & NA & $0.23 \pm 0.04^{\mathrm{b}}$ \\
\hline & homogenized & $0.02 \pm 0.00^{\mathrm{b}}$ & $0.71 \pm 0.08^{b}$ & $0.14 \pm 0.04^{\mathrm{b}}$ & $0.25 \pm 0.01 \mathrm{ab}$ \\
\hline & frozen & $0.01 \pm 0.00^{\mathrm{b}}$ & $1.22 \pm 0.15^{\mathrm{a}}$ & NA & $0.33 \pm 0.05^{\mathrm{a}}$ \\
\hline & dry & $0.14 \pm 0.01^{\mathrm{a}}$ & $0.82 \pm 0.04^{\mathrm{b}}$ & $1.07 \pm 0.14^{\mathrm{a}}$ & $0.33 \pm 0.02^{\mathrm{a}}$ \\
\hline \multirow{4}{*}{ Beetroot } & fresh & $1.29 \pm 0.03^{\mathrm{b}}$ & $2.48 \pm 0.10^{\mathrm{ab}}$ & $3.88 \pm 0.03^{\mathrm{b}}$ & $1.23 \pm 0.01^{\mathrm{b}}$ \\
\hline & homogenized & $1.57 \pm 0.08^{\mathrm{a}}$ & $2.75 \pm 0.15^{\mathrm{a}}$ & $4.36 \pm 0.13^{\mathrm{a}}$ & $1.39 \pm 0.06^{\mathrm{a}}$ \\
\hline & frozen & $1.45 \pm 0.09$ ab & $1.30 \pm 0.05^{\mathrm{c}}$ & $0.44 \pm 0.02^{\mathrm{c}}$ & $0.44 \pm 0.01^{\mathrm{d}}$ \\
\hline & dry & $0.16 \pm 0.03^{c}$ & $2.24 \pm 0.15^{\mathrm{b}}$ & $4.22 \pm 0.13^{\mathrm{a}}$ & $0.78 \pm 0.05^{c}$ \\
\hline \multirow{4}{*}{ Sunflower } & fresh & $0.49 \pm 0.02^{\mathrm{b}}$ & $1.08 \pm 0.01^{\mathrm{a}}$ & $2.95 \pm 0.08^{\mathrm{c}}$ & $0.76 \pm 0.01^{\mathrm{a}}$ \\
\hline & homogenized & $0.61 \pm 0.05^{\mathrm{a}}$ & $1.00 \pm 0.07^{\mathrm{a}}$ & $3.30 \pm 0.13^{b}$ & $0.79 \pm 0.10^{\mathrm{a}}$ \\
\hline & frozen & $0.24 \pm 0.05^{c}$ & $0.99 \pm 0.06^{\mathrm{a}}$ & $3.61 \pm 0.07^{\mathrm{a}}$ & $0.84 \pm 0.14^{\text {a }}$ \\
\hline & dry & $0.04 \pm 0.01^{\mathrm{d}}$ & $0.54 \pm 0.08^{b}$ & $0.06 \pm 0.00^{\mathrm{d}}$ & $0.43 \pm 0.04^{b}$ \\
\hline \multirow{4}{*}{ Kale } & fresh & $1.27 \pm 0.06^{\mathrm{a}}$ & $2.41 \pm 0.23^{a}$ & $4.74 \pm 0.13^{\mathrm{b}}$ & $2.38 \pm 0.09^{\mathrm{a}}$ \\
\hline & homogenized & $1.19 \pm 0.02^{\mathrm{a}}$ & $2.24 \pm 0.22^{\mathrm{a}}$ & $5.61 \pm 0.05^{\text {a }}$ & $1.96 \pm 0.11^{\mathrm{b}}$ \\
\hline & frozen & $0.53 \pm 0.04^{\mathrm{b}}$ & $1.41 \pm 0.08^{b}$ & $2.82 \pm 0.01^{\mathrm{c}}$ & $1.19 \pm 0.03^{c}$ \\
\hline & dry & $0.06 \pm 0.00^{c}$ & $0.26 \pm 0.04^{c}$ & $0.02 \pm 0.00^{\mathrm{d}}$ & $0.39 \pm 0.06^{d}$ \\
\hline
\end{tabular}

The values marked by the same letters did not differ significantly in group, considering the type of sprouts, the method of preparation of the plant material, as well as the method of evaluating the antioxidant activity. NA - no activity. Significance level $p<0.05, \mathrm{n}=3$.

amino acids, vitamins and minerals [4]. They can be easily cultivated all year round, even at home. The crop takes 5 to 14 days to mature. Five groups of crops can be distinguished: legumes (soybean, lentil, mung bean, lentil, alfalfa, azuki bean, chickpea), oilseeds (sunflower, linseed, sesame, almond, hazelnut), vegetables and herbs (broccoli, radish, kale, carrot, cabbage, celery, lettuce, parsley, beetroot, spinach and others), cereals (barley, maize, rice, oat, wheat, rye) and pseudocereals (buckwheat, amaranth, quinoa). The concentration of nutrients is high at the beginning of the plant growth phase, when usually sprouts are consumed $[4,8]$. Sprouts are known as nutritional components of higher biological value than the seeds which may contain transformed protein, higher polyunsaturated fatty acid, vitamins (mainly $\mathrm{C}$ and $\mathrm{B}$ group) and bioavailable minerals. The germination process includes biochemical changes and could be considered as a helpful method to break down the high-molecular complex materials [4, 9]. Nakamura et al. [10] determined 
Table 2

The total polyphenols content evaluated using Folin-Ciocalteu technique

\begin{tabular}{|c|c|c|c|c|}
\hline \multicolumn{5}{|c|}{$\begin{array}{c}\text { Folin-Ciocalteu } \\
{[\mathrm{mg} \text { gallic acid/g plant material }]}\end{array}$} \\
\hline Sprout & Alfalfa & Broccoli & Radish & Lentil \\
\hline Fresh & $0.10 \pm 0.01^{\mathrm{a}}$ & $0.75 \pm 0.01 \mathrm{ab}$ & $0.44 \pm 0.03^{b}$ & $0.13 \pm 0.04^{\mathrm{ab}}$ \\
\hline Homogenized & $0.09 \pm 0.02^{\mathrm{a}}$ & $0.83 \pm 0.05^{\mathrm{a}}$ & $0.56 \pm 0.02^{\mathrm{a}}$ & $0.06 \pm 0.00 \mathrm{bc}$ \\
\hline Frozen & $0.06 \pm 0.01^{\mathrm{a}}$ & $0.86 \pm 0.06^{b}$ & $0.55 \pm 0.02^{\mathrm{a}}$ & $0.16 \pm 0.01^{a}$ \\
\hline \multirow[t]{2}{*}{ Dry } & $0.09 \pm 0.01^{a}$ & $0.58 \pm 0.03^{b}$ & $0.08 \pm 0.03^{c}$ & $0.04 \pm 0.01^{c}$ \\
\hline & $\begin{array}{l}\text { Mung } \\
\text { Bean }\end{array}$ & Beetroot & Sunflower & Kale \\
\hline Fresh & $0.06 \pm 0.02^{b}$ & $0.62 \pm 0.01^{b}$ & $0.45 \pm 0.01^{\mathrm{b}}$ & $0.92 \pm 0.04^{\mathrm{a}}$ \\
\hline Homogenized & $0.07 \pm 0.01^{b}$ & $0.81 \pm 0.04^{\mathrm{a}}$ & $0.52 \pm 0.02^{a}$ & $0.93 \pm 0.01^{\mathrm{a}}$ \\
\hline Frozen & $0.04 \pm 0.00^{b}$ & $0.24 \pm 0.04^{c}$ & $0.37 \pm 0.04^{c}$ & $0.38 \pm 0.02^{b}$ \\
\hline Dry & $0.17 \pm 0.03^{a}$ & $0.59 \pm 0.04^{b}$ & $0.09 \pm 0.02^{d}$ & $0.13 \pm 0.02^{c}$ \\
\hline
\end{tabular}

The values marked by the same letters did not differ significantly in group, considering the type of sprouts as well as the method of preparation the plant material. Significance level $p<0.05, \mathrm{n}=3$.

Table 3

The correlation coefficients $(r)$ and statistical significance $(p)$ between the obtained results

\begin{tabular}{|c|c|c|c|c|}
\hline & ABTS & FRAP & Folin-Ciocalteu & CUPRAC \\
\hline DPPH & $0.705^{*}$ & $0.814^{*}$ & $0.842^{*}$ & $0.741^{*}$ \\
\hline ABTS & & $0.748^{\star}$ & $0.804^{*}$ & $0.759^{*}$ \\
\hline FRAP & & & $0.953^{*}$ & $0.910^{*}$ \\
\hline Folin-Ciocalteu & & & & $0.954^{*}$ \\
\hline
\end{tabular}

${ }^{*} p<0.001$

Table 4

Statistical significance of differences between the potential of particular sprouts extracts, assessed by the Wilcoxon signed-rank test $(p<0.05)$

\begin{tabular}{|c|c|c|c|c|c|c|c|}
\hline & Broccoli & Radish & Lentil & $\begin{array}{l}\text { Mung } \\
\text { Bean }\end{array}$ & Beetroot & Sunflower & Kale \\
\hline Alfalfa & $\begin{array}{l}z=3.920 \\
p<0.001\end{array}$ & $\begin{array}{l}\mathrm{z}=3.883 \\
p<0.001\end{array}$ & NS & NS & $\begin{array}{l}z=3.771 \\
p<0.001\end{array}$ & $\begin{array}{l}\mathrm{z}=3.808 \\
p<0.001\end{array}$ & $\begin{array}{l}z=3.659 \\
p<0.001\end{array}$ \\
\hline Broccoli & & $\begin{array}{l}z=3.472 \\
p<0.001\end{array}$ & $\begin{array}{l}z=3.823 \\
p<0.001\end{array}$ & $\begin{array}{l}z=3.920 \\
p<0.001\end{array}$ & NS & $\begin{array}{l}z=3.920 \\
p<0.001\end{array}$ & NS \\
\hline Radish & & & $\begin{array}{l}z=3.696 \\
p<0.001\end{array}$ & $\begin{array}{l}z=3.136 \\
p<0.002\end{array}$ & NS & $\begin{array}{l}z=3.509 \\
p<0.001\end{array}$ & NS \\
\hline Lentil & & & & $\begin{array}{l}z=1.979 \\
p<0.050\end{array}$ & $\begin{array}{l}z=3.621 \\
p<0.001\end{array}$ & $\begin{array}{l}z=2.688 \\
p<0.020\end{array}$ & $\begin{array}{l}z=3.285 \\
p<0.002\end{array}$ \\
\hline $\begin{array}{l}\text { Mung } \\
\text { Bean }\end{array}$ & & & & & $\begin{array}{l}\mathrm{z}=3.920 \\
p<0.001\end{array}$ & $\begin{array}{l}z=2.800 \\
p<0.010\end{array}$ & $\begin{array}{l}z=3.136 \\
p<0.002\end{array}$ \\
\hline Beetroot & & & & & & $\begin{array}{l}z=2.837 \\
p<0.010\end{array}$ & NS \\
\hline Sunflower & & & & & & & $\begin{array}{l}z=2.837 \\
p<0.010\end{array}$ \\
\hline
\end{tabular}

NS - not statistically significant differences 
isoflavonoids content in beans and sprouts consumed in Japan. They found the higher content of these compounds in soybean sprouts than in legume species sprouts as green pea, black mappe or green gram (mung bean). Ramesh et al. [11] evaluated antioxidant potentials of methanolic extracts of sprouts and seeds of Vigna radiata (mung bean) and Macrotyloma uniflorum and found higher total antioxidant capacity of sprouts as compared to seeds samples.

In our study, the alfalfa, broccoli, radish, lentil, mung bean, beetroot, sunflower and kale sprouts were taken into consideration due to their availability at the local market. The high antioxidant potential was found for beetroot and kale sprouts extracts, depending on the measurement method. Also, high values were found for broccoli sprouts extracts. In general, the lower potential was observed for alfalfa, lentil, and mung bean sprouts. Boivin et al. [12] carried out a study on antiproliferative and antioxidant activity of common vegetables and found high chemopreventive potential for beetroot and broccoli juice as well as the very high for kales juice.

Taking into account mature plants, it should be added that Halvorsen et al. [13] found the highest antioxidant activity, evaluated with FRAP method, for the plants also tested in our study, i.e. for sunflower seed $-5.39 \mathrm{mmol} / 100 \mathrm{~g}$. They evaluated the antioxidant potential of dietary plant extracts sonicated in extractant containing $90 \%$ methanol and $10 \%$ water. In their study, kale and beetroot also showed high activity -2.34 and $1.98 \mathrm{mmol} / 100 \mathrm{~g}$, respectively. Lower activities were found for broccoli -0.58 , lentil -0.49 , radish -0.40 and mung bean $-0.35 \mathrm{mmol} / 100 \mathrm{~g}$, but alfalfa was not evaluated. In our study, the sprouts belonging to the Fabaceae ( $L e$ guminosae) family as alfalfa, lentil, and mung bean also showed lower potential, whereas higher ferric ion reducing power was found for kale, broccoli, beetroot, and radish. Gill et al. [14] confirmed the health-promoting effect of cruciferous and leguminous sprouts in a human diet. Volunteers were fed daily $113 \mathrm{~g}$ of these sprouts for two weeks. Authors concluded that cruciferous vegetable consumption may be linked to a reduced risk of cancer due to their decreasing effect on DNA damages.

Sprouts are usually applied as crispy additives to appetizers, salads, sandwiches or soups to improve their texture and flavor. They can be eaten raw as fresh or cooked, canned as well as frozen. According to Ebert [8], such processing may unfavorably affect sprouts nutritional value. On the contrary, other processes as ultrasounds application on seeds, before starting germination, seems to be useful to enhance their nutritional quality. Yang et al. [15] studied the impact of ultrasound on soybean seeds and found an increase of germination rate, sprout length, GABA, daidzein and genistein contents as compared with sprouts untreated ultrasonically. In our study, extracts prepared from frozen material showed high potential especially for radish, broccoli, lentil, and sunflower sprouts whereas fresh in case of kale, lentil and alfalfa sprouts. The higher activities were found mainly for homogenized material, whereas the lowest for the majority of dry sprouts. It can suggest that drying of plant material in temperature $+40^{\circ} \mathrm{C}$ seems to have an unfavorable effect on the antioxidant activity of evaluated sprouts. Similar results were obtained by Yen and $\mathrm{Vu}[16]$ on the impact of various drying procedures on Limnophila aromatica antioxidant activity. In their study, the drying at $40^{\circ} \mathrm{C}$ resulted in the most antioxidant activity decreasing. The drying at $50^{\circ} \mathrm{C}$ was found suitable for convection and at $60^{\circ} \mathrm{C}$ for vacuum drying in antioxidant properties retaining. The authors noticed that freeze drying was effective to retain high antioxidant capacity. To the similar conclusions came Valadez-Carmona et al. [17] who observed in coconut husk dried using the oven- and microwave drying lower antioxidant potential and phenolic compounds content as compared to fresh. The decreasing of vanillin, vanillic acid, catechin, and kaempferol content was also noticed. Kamiloglu et al. [18] in their review on the effect of drying on antioxidant potential of fruits and vegetables concluded that in some cases a spectacular increase of the antioxidant compounds content was found, however in general a decreasing of these properties was observed. Authors suggested that these changes could be caused by thermal degradation or oxidation process and may depend on various factors as plant ripeness, agricultural treatments and environmental conditions as light and presence of oxygen or physical properties of plant material as texture and thickness.

A common method to increase the bioavailability of active components is a homogenization of the sample with the solvent. The material is poured with a suitable solvent and ground by mixing or grinding, then separated from the insoluble residue by filtration or centrifugation [19]. Torti et al. [20] compared the conventional ultrasound-assisted extraction method with homogenization. They noticed that the last-mentioned method seemed to be more efficient to extract phenolics from Acomastylis rossii and Ouratea lucens leaves and suggested that the application of homogenizer might lead to increase phenolic yield and efficiency. Another technique of homogenization is high-pressure process which was applied by Colle et al. [21] during their study on the tomato pulp lycopene bioaccessibility. This type of homogenization, followed by thermal processing, could lead to 
tomato cell structures breakdown, however, on the other hand, it could improve the fiber network strength. An inverse relationship between the pressure of homogenization, and thus the tomato network strength, and the lycopene in vitro bioaccessibility was noticed.

As already mentioned, sprouts are considered to be material of rather short storage life. One of the ways to prolong this parameter may be freezing - a quick and controlled reduction of product temperature to even $-30^{\circ} \mathrm{C}[22,23]$. It may result in increased bioavailability of extracts of active compounds. In our study extracts of frozen material showed high potential especially for radish, broccoli, lentil, and sunflower. Freezing may lead to damage of plants cell walls and then increase active substances permeation into the solvent. Zhao et al. [24] evaluated the antioxidant potential and nutritional quality of nectarine fruits after storage at near freezing temperature $\left(-1.5^{\circ} \mathrm{C}\right.$ to $\left.-1.2^{\circ} \mathrm{C}\right)$ and found such a method to be effective. They observed an improvement of many fruit extracts parameters, including antioxidant activity, i.e. radical scavenging activity, metal-chelating ability, reducing power as well as the content of ascorbic acid, polyphenols, and flavonoids after such processing. Moreover, Poiana et al. [25] evaluated the effect of home freezing and storage at $-18^{\circ} \mathrm{C}$ for up to 10 months on the antioxidant potential of selected fruits: strawberry, sweet cherry, and sour cherry. The content of polyphenols, anthocyanins and vitamin $C$, as well as antioxidant activity, was assessed. They found that the storage up to 4 months did not significantly influence the bioactive compounds concentration or color indices whereas the longer storage may result in greater loss of antioxidant properties, especially in strawberries. Their results might suggest that the freezing should be adapted to the type of plant material and to the possible changes in the content of active substances.

\section{CONCLUSION}

In our study the higher antioxidant potential was found for beetroot and kale sprouts extracts, depending on the measurement method. Also, high activity was found for broccoli sprouts extracts. The lower potential, in general, was observed in the case of alfalfa, lentil, and mung bean sprouts. All extracts determined by the DPPH, ABTS, FRAP and F-C method showed the antioxidant potential in contrary to those evaluated with the CUPRAC method, where not every plant showed activity. Drying seems not to be a favorable method to sprouts processing taking into account their antioxidant activity, whereas the potential of homogenized, frozen and fresh material extracts has been satisfactory.
Conflict of interest: The authors declare no conflict of interest.

\section{REFERENCES}

1. Zielonka-Brzezicka J, Nowak A, Zielińska M, Klimowicz A. Porównanie właściwości przeciwutleniających wybranych części maliny właściwej (Rubus idaeus) i jeżyny europejskiej (Rubus fruticosus). Pomeranian J Life Sci 2016; 62(4):5259. doi: http://dx.doi.org/10.21164/pomjlifesci.269

2. Lewicki PP. Kiełki nasion jako źródło cennych składników odżywczych. Żywn Nauka Technol Jakość 2010; 6(73):18-33.

3. Samotyja U, Zdzieblowski T, Szlachta M, Malecka M. Przeciwutleniające właściwości ekstraktów z kiełków roślin. Żywn Nauka Technol Jakość 2007; 14(5):122-128.

4. Marton M, Mandoki ZS, Csapo-Kiss ZS, Csapo J. The role of sprouts in human nutrition. A review. Acta Univ Sapientiae Aliment 2010; 3:81-117.

5. Drużyńska B, Kostrzewski K, Majewska E, Kowalska J, Derewiaka D, Ciecierska M. Zawartość wybranych składników bioaktywnych i ich aktywność przeciwrodnikowa w kiełkach nasion. Zesz Probl Post Nauk Roln 2015; 58:345-354.

6. Muzykiewicz A, Zielonka-Brzezicka J, Klimowicz A. The antioxidant potential of flesh, albedo and flavedo extracts from different varieties of grapefruits. Acta Sci Pol Technol Aliment 2019; 18(4):453-462. http://dx.doi.org/ 10.17306/J.AFS.0731

7. Apak R, Güçlü K, Özyürek M, Karademir SE. Novel total antioxidant capacity index for dietary polyphenols and vitamins $\mathrm{C}$ and $\mathrm{E}$, using their cupric ion reducing capability in the presence of neocuproine: CUPRAC method. J Agric Food Chem 2004; 52(26):7970-7981. doi: http://dx.doi. org/10.1021/jf048741x

8. Ebert AW. Sprouts, microgreens, and edible flowers: the potential for high value specialty produce in Asia. In: Proceedings SEAVEG 2012. High value vegetables in Southeast Asia: production, supply and demand; 2012 Jan 24-26; Chiang Mai, Thailand. 2013:216-227. 
9. Di Gioia F, Renna M, Santamaria P. Sprouts, microgreens and 'baby leaf' vegetables. In: Yildiz F, Wiley RC, eds. Minimally processed refrigerated fruits and vegetables. $2^{\text {nd }}$ ed. Boston. Springer, 2017:403-432. doi: http://dx.doi.org/10.1007/9781-4939-7018-6_11

10. Nakamura Y, Kaihara A, Yoshii K, Tsumura Y, Ishimitsu S, Tonogai Y. Content and composition of isoflavonoids in mature or immature beans and bean sprouts consumed in Japan J Health Sci 2001; 47(4):394-406. doi: http://dx.doi. org/10.1248/jhs.47.394

11. Ramesh CK, Rehman A, Prabhakar BT, Vijay Avin BR, Aditya Rao SJ. Antioxidant potentials in sprouts vs. seeds of Vigna radiata and Macrotyloma uniflorum. J App Pharm Sci 2011; 1(7):99-110.

12. Boivin D, Lamy S, Lord-Dufour S, Jackson J, Beaulieu E, Côté M et al. Antiproliferative and antioxidant activities of common vegetables: A comparative study. Food Chem 2009; 112(2):374-380. doi: http:// dx.doi.org/10.1016/j.foodchem.2008.05.084

13. Halvorsen BL, Holte K, Myhrstad MC, Barikmo I, Hvattum E, Remberg SF et al. A systematic screening of total antioxidants in dietary plants. J Nutr 2002; 132(3):461-471. doi: http://dx.doi. org/10.1093/jn/132.3.461

14. Gill CI, Haldar S, Porter S, Matthews S, Sullivan $S$, Coulter J et al. The effect of cruciferous and leguminous sprouts on genotoxicity, in vitro and in vivo. Cancer Epidemiol Biomarkers Pre 2004; 13(7):1199-1205.

15. Yang H, Gao J, Yang A, Chen H. The ultrasoundtreated soybean seeds improve edibility and nutritional quality of soybean sprouts. Food Res Int 2015;77:704-710. doi: http://dx.doi.org/10.1016/j. foodres.2015.01.011

16. Yen TTN, Vu NH. Effect of drying method to antioxidants capacity of Limnophila aromatica. In: AIP Conference Proceedings; 2017 Sep; 1878(1):020036. AIP Publishing LLC; New York, USA. doi: http://dx.doi.org/10.1063/1.5000204

17. Valadez-Carmona L, Cortez-García R M, Plazola-Jacinto C P, Necoechea-Mondragón H, OrtizMoreno A. Effect of microwave drying and oven drying on the water activity, color, phenolic compounds content and antioxidant activity of coconut husk (Cocos nucifera L.). J Food Sci Technol
2016; 53(9):3495-501. http://dx.doi.org/10.1007/ s13197-016-2324-7

18. Kamiloglu S, Toydemir G, Boyacioglu D, Beekwilder J, Hall R D, Capanoglu E. A review on the effect of drying on antioxidant potential of fruits and vegetables. Crit Rev Food Sci Nutr 2016; 56(1):S110-129. doi: http://dx.doi.org/10.1080/1 0408398.2015 .104596

19. Malinowska M, Sikora E, Ogonowski J. Ekstrakt z brzozy jako źródło substancji biologicznie czynnych. Przem Chem 2014; 93(9):1548-155. doi: http://dx.doi.org/10.12916/przemchem.2014.1548

20. Torti SD, Dearing MD, Kursar TA. Extraction of phenolic compounds from fresh leaves: a comparison of methods. J Chem Ecol 1995; 21(2):117125. doi: http://dx.doi.org/10.1007/BF02036646

21. Colle I, Van Buggenhout S, Van Loey A, Hendrickx M. High pressure homogenization followed by thermal processing of tomato pulp: influence on microstructure and lycopene in vitro bioaccessibility. Food Res Int 2010; 43(8):2193-2200. doi: http://dx.doi.org/10.1016/j.foodres.2010.07.029

22. Fiutak G, Hajduk E, Filipczak-Fiutak M, Macura R, Firek B. Wpływ wybranych procesów termicznych na zachowanie właściwości przeciwutleniających homogenatów z owoców jagodowych. Żywn Nauka Technol Jakość 2016; 2(105):106-117.

23. Paciulli M, Ganino T, Pellegrini N, Rinaldi M, Zaupa M, Fabbri A, Chiavaro E. Impact of the industrial freezing process on selected vegetables Part I. Structure, texture and antioxidant capacity. Food Res Int 2015; 74:329-337. doi: http://dx.doi. org/10.1016/j.foodres.2014.04.019

24. Zhao H, Shu C, Fan X, Cao J, Jiang W. Near-freezing temperature storage prolongs storage period and improves quality and antioxidant capacity of nectarines. Sci Hort 2018; 228:196-203. doi: http://dx.doi.org/10.1016/j.scienta.2017.10.032

25. Poiana MA, Moigradean D, Alexa E. Influence of home-scale freezing and storage on antioxidant properties and color quality of different garden fruits. Bulg J Agric Sci 2010; 16(2):163-171. 